\title{
Zn-Al Hydrotalcite As Adsorbent on Metal Waste (Cu2 + ): Case Study of Liquid Waste in Integrated Laboratory Center UIN Syarif Hidayatullah
}

\author{
Nurmaya Arofah ${ }^{a^{*}}$, Eka Fitriani Ahmad ${ }^{\mathrm{b}}$ \\ ${ }^{\mathrm{a}, \mathrm{b}}$ Department of Chemistry, Faculty of Science and Technology \\ Syarif Hidayatullah State Islamic University (UIN) \\ Jakarta, Indonesia \\ *Email : nurmayaarofah@uinjkt.ac.id
}

\begin{abstract}
Central Chemical Laboratory of Integrated Lab UIN Syarif Hidayatullah is one of the largest wastewater containing hazardous materials is high enough, one of which is metal $\mathrm{Cu} 2+$. The most effective method for reducing heavy metal pollutants are adsorption, adsorbent consists of two types namely cationic and anionic adsorbent. The advantages of the adsorbent aniok is easily synthesized, so it is more effective than the cationic absorbent. Type of anionic adsorbent is hydrotalcite. Material hydrotalcite synthesized using methods kopresitipasi with the basic materials for the $\mathrm{Mg}$ / Al hydrotalcite is $\mathrm{MgCl} 2.6 \mathrm{H} 2 \mathrm{O}$ with $\mathrm{AlCl} 3.6 \mathrm{H} 2 \mathrm{O}$ and for $\mathrm{Zn}-\mathrm{Al}$ hydrotalcite is $\mathrm{ZnSO} 4.7 \mathrm{H} 2 \mathrm{O}$ and $\mathrm{AlCl} 3.6 \mathrm{H} 2 \mathrm{O}$. The results of this research to know the characteristics of the adsorbent of $\mathrm{Mg} / \mathrm{Al}$ hydrotalcite and $\mathrm{Zn} / \mathrm{Al}$ hydrotalcite in which the $\mathrm{Cu} 2+$ metal mengadsorb characterization of $\mathrm{Mg} / \mathrm{Al}$ hydrotalcite had basal spacing $\mathrm{d} 003 \AA=7.57, \mathrm{~d} 006=3.80 \AA \hat{\mathrm{A}}, \mathrm{d} 009=2.57 \AA$ and $\mathrm{Zn} / \mathrm{Al}$ hydrotalcite had basal spacing $\mathrm{d} 003 \AA=7.54, \mathrm{~d} 006=3.78$ $\hat{\AA}, \mathrm{d} 009=2.59 \AA \hat{\text {. }}$. In addition, the structure of $\mathrm{Zn} / \mathrm{Al}$ hydrotalcite has a relative content or purity is as high as 91.74\% when compared with $\mathrm{Mg} / \mathrm{Al}$ hydrotalcite that only contain relative or purity of the sample is only about $81.3 \%$. The higher the relative content of a substance, the greater the absorption in a metal adsorbing $\mathrm{Cu} 2+$ so that optimization of the adsorption capacity of $\mathrm{Zn} \mathrm{/} \mathrm{Al}$ hydrotalcite to metal $\mathrm{Cu} 2+$ is greater when compared with $\mathrm{Mg} \mathrm{/} \mathrm{Al}$ hydrotalcite. $\mathrm{Cu}$ metal ion adsorption by hydrotalcite satisfy the equation Langmuir and Freundlich adsorption isotherm. Determination of adsorption capacity of the zeolite to the most appropriate waste $\mathrm{Cu}$ is using Freundlich adsorption equation compared with the Langmuir adsorption equation. The maximum adsorption capacity of $\mathrm{Mg} / \mathrm{Al}$ hydrotalcite and $\mathrm{Zn} / \mathrm{Al}$ hydrotalcite against waste adsorption $\mathrm{Cu}$ is $2.114 \mathrm{mg} / \mathrm{g}$ and $1.284 \mathrm{mg} /$ gram.
\end{abstract}

Keywords: Waste metals $\mathrm{Cu} 2+, \mathrm{Mg} / \mathrm{Al}$ hydrotalcite and $\mathrm{Zn} / \mathrm{Al}$ hydrotalcite

\section{Introduction}

The laboratory is one of the producers of waste water with hazardous materials that are quite high, so it required a processing before dumped into the bodies water recipient as not to pollute the environment. Currently most of the wastewater laboratory in particular where are in universities in Indonesia are not processed properly because of technology problems and costs. Of the amount, liquid waste produced by a lab generally indeed relatively few, but this heavily contaminated liquid waste by different types of toxic chemicals. Collectively and in a long period of time can be a real impact on the environment if not managed adequately.

Leaching of metals copper $\left(\mathrm{Cu}^{2+}\right)$ in the aquatic environment can cause hazard to the health of humans, animals or plants. When copper metal content in aquatic ecosystems exceed maximum concentration limit then the process can occur bioaccumulation process in living organisms, such as fish, shrimp, and biota. $\mathrm{Cu}$ metal in the form of metallo-proteins can indicate oxidation reduction, activity of $\mathrm{Cu}^{2+}$ being $\mathrm{Cu}^{+}$that can change the structure and function of proteins in living organisms. When $\mathrm{Cu}$ enter and accumulate in the human body in high concentrations can be toxic and cause damage to the liver and kidneys through strong ties with the residues metalotionin [1].

Separation of heavy metal $\mathrm{Cu}$ from waste laboratory education is the most basic interests. Various methods have been developed to separate the metals $\mathrm{Cu}$ from waste water, among others, by the method of sedimentation, flocculation, ion exchanger, oxidation reduction, membrane system, and method of adsorption. Adsorption is the most effective method for reducing heavy metal pollutants. Various types of material adsorbent has been widely developed in minimizing heavy metal impurities in the water, such as zeolites, bentonite, humic acid, activated carbon, soil diatome, and hydrotalcite.

Hydrotalcite compound is a layered double hydroxide which has negatively charged layer with cation on interlayer [2]. Hydrotalcite-like anionic clays are less numerous in nature compared to cationic clay, yet anionic clays is more easily synthesized [3]. Hydroxide layer structure similar to brucite is known as layer double hydroxides (Cavani et al., 1991) with the general formula $\left[\mathrm{M}^{2+}{ }_{1-x} \mathrm{M}^{3+}{ }_{x}(\mathrm{OH})_{2}\right]^{x+}\left[\mathrm{A}^{\mathrm{n}-}{ }_{b / n}\right] \cdot m \mathrm{H}_{2} \mathrm{O}$, where $\mathrm{M}^{2+}$ dan $\mathrm{M}^{3+}$ is the divalen and trivalen cation on octahedral position in 
hydroxide layer which is surrounded with 6 hydroxide cluster with $\mathrm{x}$ normal range between 0.17 up 0.33 . Meanwhile, $\mathrm{An}^{-}$is organic or inorganic anion on the interlayer which is caused by the presence of positive charge on the surface of hydrotalcite. The parameter $m$ is the number of molecules of $\mathrm{H}_{2} \mathrm{O}$ [4]. Hydrotalcite is usually produced by the addition of aqueous $\mathrm{Na}_{2} \mathrm{CO}_{3}$, or $\mathrm{NaOH}$ together with aqueous $\mathrm{MgSO}_{4}$ and $\mathrm{AlCl}_{3}$ [5].

Hydrotalcite is one of material interesting, prospective, and promising, because it can be useful in various applications [6]. In its application, the hydrotalcite has the ability as a catalyst, solid of supporting catalyst, exchange of anion, an adsorbent, and as a stabilizer [7]. In that case, the use of hydrotalcite as waste water adsorbent especially $\mathrm{Cu}$ metal became particularly an effective solution.

Adsorption of dissolved substances (of a solution) on the adsorbent solid is very crucial. The application of the using

this principle are color removal solution (decolorizing) using a pumice stone (charcoal) and separation process by using chromatography techniques. The adsorption isotherme approach quite satisfactoily explained by H. Freundlich. According to Freundlich, if $y$ is the weight of the dissolved substance per gram of adsorbent and $\quad c$ is the concentration of a substance dissolved in the solution. The concept can be derived from the equation as follows:

$\frac{X_{m}}{m}=k \cdot C^{1 / n}$

$\log =\left(\frac{X_{m}}{m}\right)=\log k+\frac{1}{n} \cdot \log C(2)$ that: $X m=$ the weight of a substance in adsorption

$$
\begin{array}{ll}
m & =\text { the weight of zeolite } \\
C & =\text { the concentration of a substance }
\end{array}
$$

$K$ and $n$ is a constant adsorption that it depends on adsorbent type and adsorption temperature. If $\log (\mathrm{Xm} / \mathrm{m})$ towards $\log \mathrm{C}$ was created, it will be retrieved by $\log \mathrm{k}$ as the intercept and $1 / \mathrm{n}$ as the slope in linear equation, so that the values of $\mathrm{k}$ and $\mathrm{n}$ can be calculated.

In 1918, Langmuir lowered the theory of adsorption isotherme by using a simple model in the form of a solid surface will adsorbed gases. This model defines the maximum adsorption capacity that occur due to the present of a monolayer adsorbant on the surface of tadsorbent. Langmuir's approach includes five absolute assumptions:

1. Gases in adsorption behave ideally in steam phase.

2. Gases in adsorption limited to monolayer coating.

3. The surface of adsorbant homogeneous, which means that the affinity of each bond position to the gas molecules is similar.
4. There is no lateral interaction between adsorbat molecules.

5. Gas molecules localized, meaning that they are not moving on the surface.

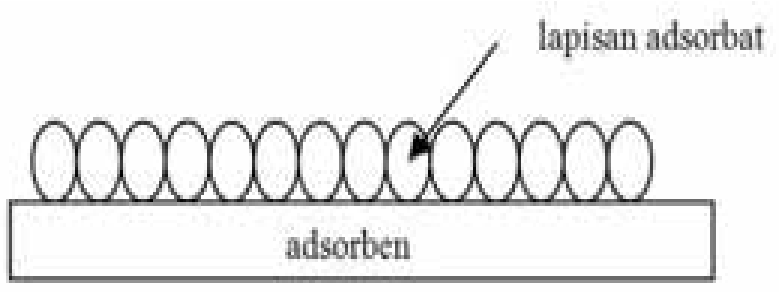

Figure 1. Illustration of adsorption in Langmuir equation

Langmuir equation is:

$$
\begin{aligned}
\frac{X_{m}}{m} & =\frac{a \cdot C}{1+b \cdot C} \\
\frac{m \cdot C}{X m} & =\frac{1}{a}+\left(\frac{b}{a}\right) \cdot C
\end{aligned}
$$

by making the curve $m . c / X m$ toward $C$ will be obtained with linear equations which the intercept is $1 / a$ and the slope is $(b / a)$, so that the value of $a$ and $b$ can be calculated, from the large to the small values of $a$ and $b$ shows the power of adsorption.

\section{Work Procedures}

The study was done with laboratory experimental methods. The study includes two phases. The first stage is the synthesis of $\mathrm{Zn}-\mathrm{Al}$ Hydrotalcite which is done with the coprecipitation methods then characterized. The second stage is the application of adsorption in metallic copper results of laboratory education waste is done in batch systems. Metals $\mathrm{Cu}$ artificial waste is used.

\subsection{Synthesis and characterization of Zn-Al hydrotalcite}

$2.87 \mathrm{~g}$ solid $\mathrm{ZnSO}_{4} .7 \mathrm{H}_{2} \mathrm{O}$ and $1.2075 \mathrm{~g} \mathrm{AlCl}_{3} \cdot 6 \mathrm{H}_{2} \mathrm{O}$ dissolved in solution of $0.1 \mathrm{M} \mathrm{Na}_{2} \mathrm{CO}_{3}$ until the volume is $500 \mathrm{~mL}$, the $\mathrm{pH}$ of the mixture retained up to 10 using $\mathrm{Na}_{2} \mathrm{CO}_{3}$. The solution has the ratio of moles of $\mathrm{Zn} / \mathrm{Al} 2: 1$. Furthermore the solution stirred using a magnetic stirrer for 15 minutes, then reflux at temperature $70^{\circ} \mathrm{C}$ for 1 hour and is deposited for 1 night. During the deposition process, the filtrate is washed using aquadest to free $\mathrm{Cl}$ ion using a solution of $\mathrm{AgNO}_{3} \quad 0.1 \mathrm{M}$ until the filtrate is colorless (clear). $\mathrm{Cl}$ free sediment centrifuged for $15 \mathrm{~min}$ at 2800 rpm and at the final stage of washed with aquadest. The resulting solid is then in the oven at a temperature of $100^{\circ} \mathrm{C}$ for 15 hours. Hydrotalcite $\mathrm{Zn}-\mathrm{Al}$ products were analyzed by XRD (figure 2). 


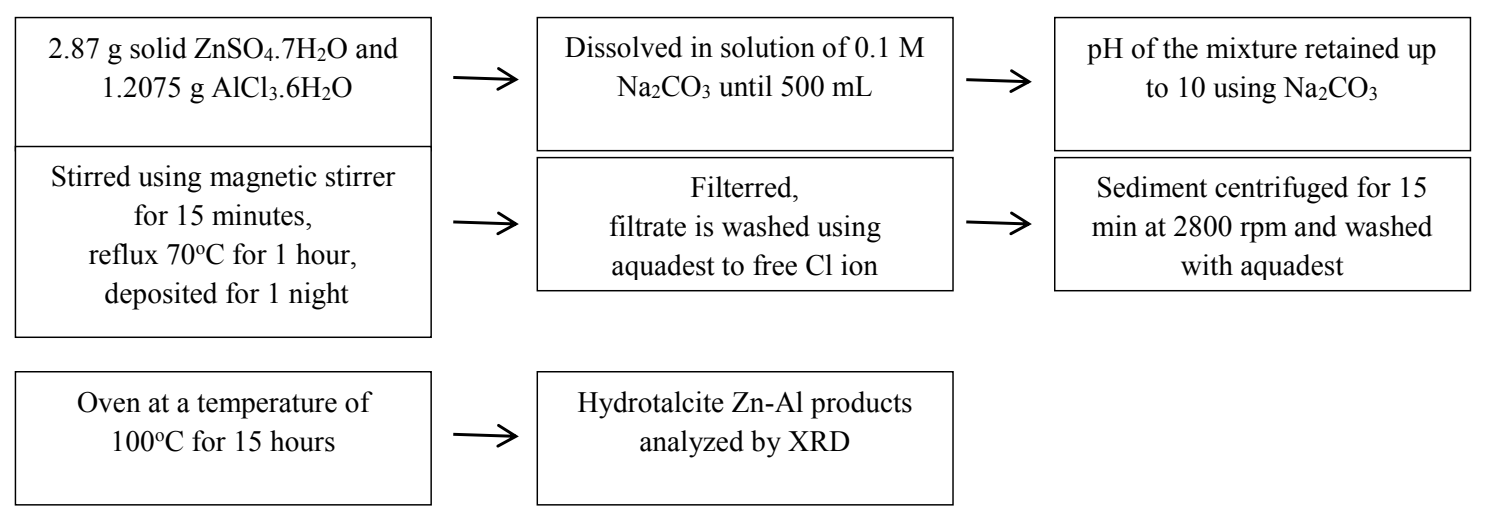

Figure 2. Synthesis and characterization of Zn-Al hydrotalcite

\subsection{Determination of Adsorption Isotherme}

$0.5 \mathrm{~g} \mathrm{Zn}-\mathrm{Al}$ was put into a beaker glass and was added $25 \mathrm{~mL}$ of $\mathrm{CuSO}_{4} .5 \mathrm{H}_{2} \mathrm{O}$ solution with each concentration of $0.02 ; 0.04 ; 0.06$; and $0.08 \mathrm{~N}$. Solution was stirred for 1 hour then filtered, filtrate was put in the Erlenmeyer flask
$100 \mathrm{~mL}$ and analyzed by Iodometri titration method using $\mathrm{Na}_{2} \mathrm{~S}_{2} \mathrm{O}_{3} .5 \mathrm{H}_{2} \mathrm{O}$ solution which has been standardized and KI $1 \mathrm{~N}$ as much as $5 \mathrm{~mL}$, observed the color change that occurs from the yellow color becomes colorless and note the volume of $\mathrm{Na}_{2} \mathrm{~S}_{2} \mathrm{O}_{3} \cdot 5 \mathrm{H}_{2} \mathrm{O}$. Filtrate test results of adsorption are done 3 times (figure 3 ).

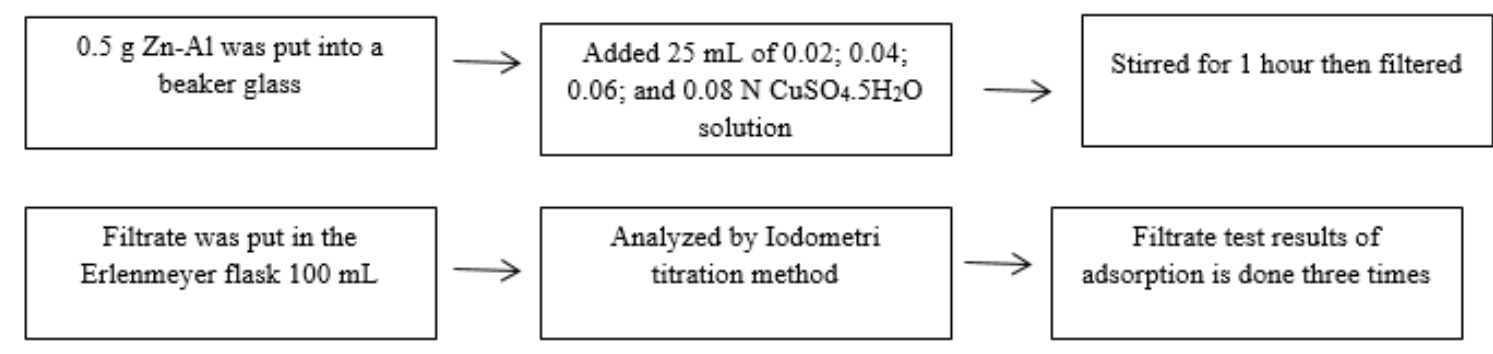

Figure 3. Determination of adsorption isotherme

\section{Data analysis}

Data obtained after making contact between the metal $\mathrm{Cu}$ in $\mathrm{CuSO} 4.5 \mathrm{H} 2 \mathrm{O}$ with $\mathrm{Zn} / \mathrm{Al}-\mathrm{Hydrotalcite}$ is the initial and final concentration. Model adsorption isotherme may be determined using Equation 2 and 4 .

\section{Results and Discussion}

\subsection{Synthesis and characterization of Hydrotalcite $\mathrm{Zn}$ -} Al

In this study, synthesis of hydrotalcite was implemented coprecipitasily with straighten up the ratio of cation and base $\mathrm{pH}$, added $\mathrm{Na}_{2} \mathrm{CO}_{3}$ solution into the other solution which it contains $\mathrm{ZnCl}_{2}$ and $\mathrm{AlCl}_{3}$ with $\mathrm{Zn} / \mathrm{Al}$ ratio (2:1) were 2,87 grams $\mathrm{ZnSO}_{4} \cdot 7 \mathrm{H}_{2} \mathrm{O}$ and 1,2075 grams $\mathrm{AlCl}_{3} \cdot 6 \mathrm{H}_{2} \mathrm{O}$ in $\mathrm{Na}_{2} \mathrm{CO}_{3}$ solution until the volume is $500 \mathrm{~mL}$, its $\mathrm{pH}$ was defensed until $\mathrm{pH}$ about to 10 by $\mathrm{Na}_{2} \mathrm{CO}_{3}$. The solution was stirred by magnetic stirrer about 15 minutes. After that, it was placed on the heater (reflux) at $70^{\circ} \mathrm{C}$ in 15 minutes and was kept in 24 hours. During that, filtrate was washed with aquadest in order to allay the $\mathrm{Cl}$ by $\mathrm{AgNO}_{3}$ solution and the filtrate is no color. Solid product was separated by centrifuge at $2800 \mathrm{rpm}$ in 15 minutes in order to separating ions. The hydrotalcite was dried with heating of oven at $100^{\circ} \mathrm{C}$ in 15 hours. The $\mathrm{Zn} / \mathrm{Al}$ hydrotalcite product is white solid and the structure will characterization by XRD.

$\mathrm{X}$-light diffraction is a method of analysis that can give some information about a crystal structure, which is it has diffraction pattern. This method is based on interaction between material and X-light electromagnetic radiation. The characterization is using $\mathrm{X}$-light diffractometer that is being able to give crystal structure in hydrotalcite $\mathrm{Zn}-\mathrm{Al}$ with $\mathrm{CO} 3$ - as balancing anion in that inter room that have basal spacing $\mathrm{d} 003=7,55 \AA$, d $006=$ $3,78 \AA \AA$, d $009=2.58780 \AA$ Á. The result of hydrotalcite $\mathrm{Zn} / \mathrm{Al}-\mathrm{CO} 3$ is displayed on diffractogram (figure 4).

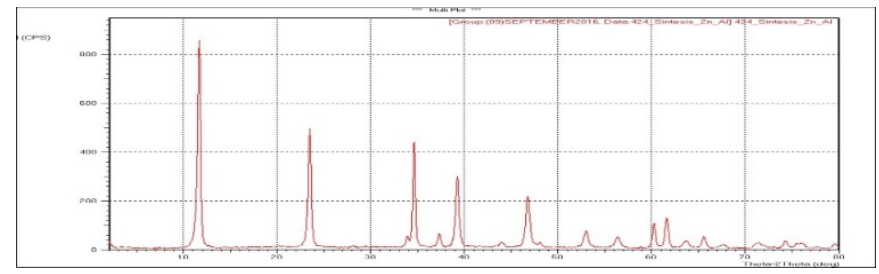

Figure 4. The result synthesis of hydrotalcite $\mathrm{Zn} / \mathrm{Al}-\mathrm{CO} 3$ diffractogram 


\subsection{Adsorption Isotherme $\mathrm{Zn}$-Al Hydrotalcite}

The processing of adsorption by an adsorbent was influenced with a lot of element and specific adsorption isotherme system. The elements that can be caused in adsorption process are types of adsorbent, the material that spared by adsorbent, surface of adsorbent, concentration of the material that spared, and temperature. However, every adsorbent has different adsorption isotherme system. Adsorption isotherme system has two types, which is Langmuir and Freundlich adsorption isotherme.

$\mathrm{Cu}^{2+}$ ions adsorption by hydrotalcite as adsorbent was inspected by reaction between adsorbent and $\mathrm{Cu}^{2+}$ solution with variation of concentration. The more $\mathrm{Cu}^{2+}$ consentration in early, $\mathrm{Cu}^{2+}$ adsorpted is more increasing in the adsorbent. The result can be seen in table 1 .

\begin{tabular}{|c|c|c|c|c|c|c|c|c|}
\hline No. & $\mathrm{C}_{0}(\mathrm{~N})$ & $\mathrm{C}_{0}(\mathrm{mg} / \mathrm{L})$ & $\mathrm{C}_{\mathrm{s}}(\mathrm{N})$ & $\begin{array}{l}\mathrm{C}_{\mathrm{s}} \\
(\mathrm{mg} / \mathrm{L})\end{array}$ & $C_{t}(N)$ & $\begin{array}{l}\mathrm{C}_{\mathrm{t}} \\
(\mathrm{mg} / \mathrm{L})\end{array}$ & $\mathbf{W}_{\text {adsorben (g) }}$ & $\begin{array}{l}\mathrm{Xm} / \mathrm{m} \\
(\mathrm{mg} / \mathrm{g})\end{array}$ \\
\hline 1 & 0.02 & 0.1248 & 0.0028 & 0.0175 & 0.0172 & 0.1073 & 0.502 & 0.2137 \\
\hline 2 & 0.04 & 0.2495 & 0.0056 & 0.0349 & 0.0344 & 0.2146 & 0.5044 & 0.4254 \\
\hline 3 & 0.06 & 0.3743 & 0.0105 & 0.0655 & 0.0495 & 0.3088 & 0.5017 & 0.6154 \\
\hline 4 & 0.08 & 0.4990 & 0.0147 & 0.0917 & 0.0653 & 0.4073 & 0.501 & 0.8130 \\
\hline
\end{tabular}

Correlation the solution concentration towards the mass of metal ions $(\mathrm{Cu})$ that is spared per 1 gram $\mathrm{Zn} / \mathrm{Al}$ hydrotalcite (Figure 5)

\section{Hubungan konsentrasi dengan massa lon $\mathrm{Cu}$ yang diadsorpsi}

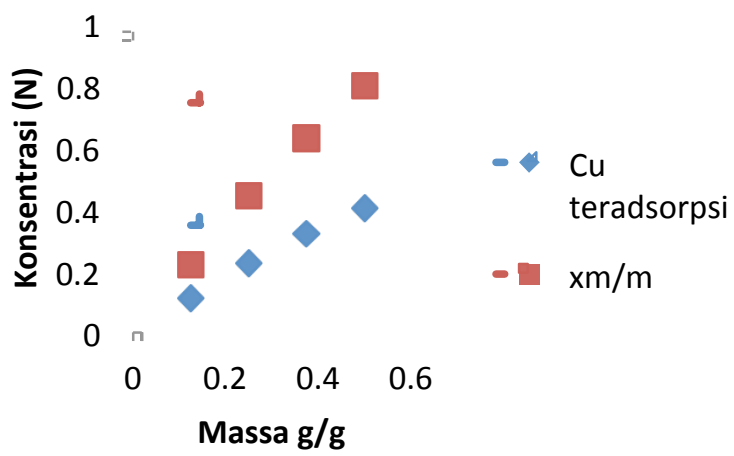

Figure 5. Correlation the solution towards the mass of metal ions that is spared.

Figure 5 showed that the more advance the $\mathrm{Cu} 2+$ ions consentrastion, the mass of $\mathrm{Cu} 2+$ ions will more increasingly spared by $\mathrm{Zn} / \mathrm{Al}$ hydrotalcite. The concentration of $\mathrm{Cu}$ solution in early is $0,1248 \mathrm{mg} / \mathrm{L}$, the $\mathrm{Cu}$ metal ion that is spared $0,2137 \mathrm{mg}$ by 1 gram $\mathrm{Zn} / \mathrm{Al}$ hydrotalcite, for the other concentration $\mathrm{Cu}$ solution is $0,2495 \mathrm{mg} / \mathrm{L}$ that is spared $0,4254 \mathrm{mg} / \mathrm{g}$, and concentration $\mathrm{Cu}$ solution is $0,3743 \mathrm{mg} / \mathrm{L}$ that is spared $0,6154 \mathrm{mg} / \mathrm{g}$ zeolite. The biggest mass from metal ions that spared in concentration $0,4990 \mathrm{mg} / \mathrm{L}$ is $0,8130 \mathrm{mg}$ metal ions by 1 gram hydrotalcite. In this case, it was appropriated from the theorist that if a solution concentration is more increase, more increasingly the mass of solute will be adsorbed. The rapid of material that adsorbed and the material that leave from the adsorbent will equally in certainly temperature.

$\mathrm{Cu}$ metal ion adsorption isotherme by hydrotalcite was calculated with the equation of Langmuir and Freundlich adsorption isotherme. Langmuir equation was implemented by using equation 1 and 2. $a$ and $k$ showed the capacity of $\mathrm{Cu}$ metal ion adsorption $\left(\mathrm{CuSO}_{4} \cdot 5 \mathrm{H}_{2} \mathrm{O}\right)$ by $\mathrm{Zn}$-Al hydrotalcite, more increase the value of $a$ in Langmuir equation and the value of $k$ in Freundlich equation showed that the adsorption capacity is more increasing. The temperature will influenced $1 / a b$ and $\log k$ values which are the adsorption rapid will be influence. To determined Langmuir and Freundlich equation in adsorption isotherme, $x / m, C e /(x / m), \log C e /(x / m)$ dan $\log$ $\mathrm{Ce}$ were calculated (table 2). Mapping results with graphs for each hydrotalcite are shown in Figures 6 and 7 below.

Table 2. Calculation of $\log (\mathrm{x} / \mathrm{m}), \log \mathrm{Ce}, \mathrm{Ce} /(\mathrm{x} / \mathrm{m})$, and Ce to Zn-Al Hyrdotalcite

\begin{tabular}{lllll}
$\mathbf{C}_{\mathbf{0}}(\mathbf{g} / \mathbf{L})$ & $\log (\mathbf{x} / \mathbf{m})$ & $\log \mathbf{C}_{\mathbf{e}}$ & $\mathbf{C e} / \mathbf{x} / \mathbf{m})$ & $\mathbf{C e}$ \\
\hline 0.1248 & $-0,6599$ & $-1,8827$ & 0,0599 & 0,0131 \\
0.2495 & $-0,3541$ & $-1,5817$ & 0,0592 & 0,0262 \\
0.3743 & $-0,2015$ & $-1,2457$ & 0,0903 & 0,0568 \\
0.4990 & $-0,0977$ & $-1,0173$ & 0,1203 & 0,0961 \\
\hline
\end{tabular}

$$
\text { Ce Vs Ce/(x/m) }
$$

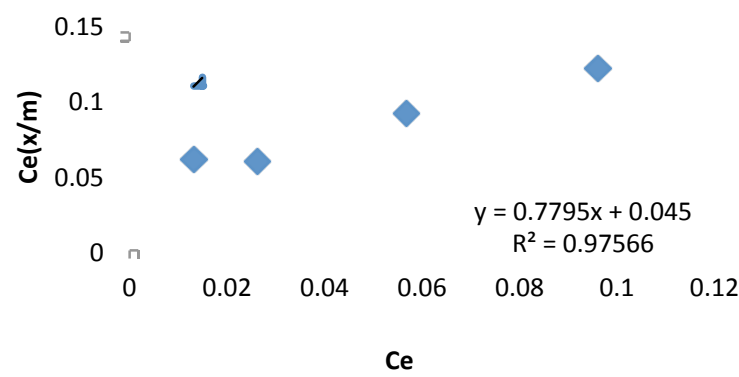

Figure 6. Equation Langmuir isotherme adsorption between $\mathrm{Ce} /(\mathrm{x} / \mathrm{m})$ versus $\mathrm{Ce}$ (Zn-Al Hydrotalcite) 
-

\section{$\log C e$ Versus $\log (x / m)$}

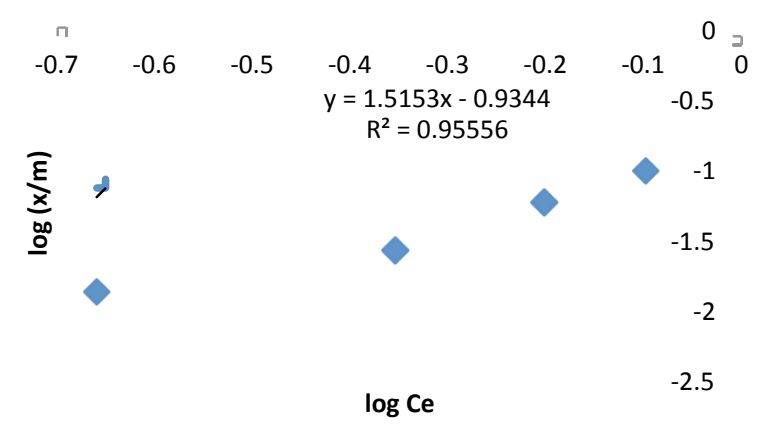

Figure 7. Equation Freundlich adsorption isotherme between log $(x / m)$ versus $\log C e$ (Zn-Al Hydrotalcite)

The Results of Langmuir and Freundlich equation in Zn-Al Hydrotalcite were proved with good curve of linear graphic and also $\mathrm{R}^{2}$ value was come closer to number 1 . Figure 8 and 9 proved that adsorption equation in $\mathrm{CuSO}_{4} \cdot 5 \mathrm{H}_{2} \mathrm{O}$ by $\mathrm{Zn}-\mathrm{Al}$ hydrotalcite, Langmuir and Freundlich equation were filled, with $\mathrm{R}^{2}=0,975$ and $\mathrm{R}^{2}=0,955$. It also can be applied in process of $\mathrm{Cu}$ metal ion adsorption in $\mathrm{CuSO}_{4} .5 \mathrm{H}_{2} \mathrm{O}$ by $\mathrm{Zn}-\mathrm{Al}$ hydrotalcite. The value of its contants is displayed on table 3 .

Table 3. The Constants in Langmuir dan Freundlich to $\mathrm{Zn}-\mathrm{Al}$ Hydrotalcite

\begin{tabular}{lll}
\hline Isoterm & Konstanta & Harga \\
\hline Langmuir & $\mathrm{a}$ & 2,114 \\
& $\mathrm{~b}$ & 10,28 \\
Freundlich & $\mathrm{k}$ & 8.649 \\
& $\mathrm{n}$ & 0.392 \\
\hline
\end{tabular}

Table 3 showed about Langmuir and Freundlich constants in $\mathrm{Zn}-\mathrm{Al}$ hydrotalcite. The model of Freundlich equation was assuming that it has multilayer and heterogeneous, because of the existence of difference from energy in every side of the adsorbent where adsorption process in sides as follow Langmuir adsorption isotherme [8]. The act of determining about the maximum adsorption capacity $\mathrm{Zn}-\mathrm{Al}$ hydrotalcite in $\mathrm{Cu}$ metal adsorption was calculated by using Langmuir equation because it has monolayer process in hydrotalcite surface per mg $\mathrm{Cu}$ metal ions that adsorbed/gram hydrotalcite. The result showed that capacity of adsorption in maximum was 1,284 $\mathrm{mg}$ /grams.

\section{Conclusion}

The conclusions that can be drawn from this study are:

1. Known the characterization of $\mathrm{Zn} / \mathrm{Al}$-hydrotalcite have

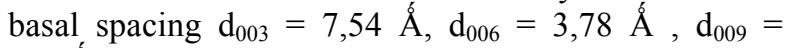
$2.59 \AA ̊$.

2. Structure of $\mathrm{Zn} / \mathrm{Al}$-hydrotalcite has a very high purity that is $91.74 \%$. The higher purity of a compound is, then the greater absorption in adsorbing metal copper.

3. Metal copper ion adsorption process by hydrotalcite filled the Langmuir and Freundlich adsorption equation isotherme. Determination of the adsorption capacity of zeolite against waste $\mathrm{Cu}$ 's most appropriate to use Freundlich adsorption equation compared to Langmuir. Maximum adsorption capacity of $\mathrm{Zn} / \mathrm{Al}$-hydrotalcite against waste metal copper is $1.284 \mathrm{mg}$ gram.

\section{References}

[1] Palar, H., 1994, "Pencemaran dan Toksikologi Logam Berat", Rineka Cipta, Jakarta.

[2] Bejoy, N., 2001, "Hydrotalcite : The Clay that Cures", Resonance.

[3] Zhu, M.X., Li, Y.P., Xie, M. and Xin, H.Z., 2005, Sorption of an anionic dye by uncalcined and calcined layered double hydroxides : a case study, Journal of Hazardous Materials, 120, 163-171.

[4] Jinhong, M., Hui, Z., Evans, D. G., and Xue, D., 2005, Novel Layer Pesticide Slow/Controlled Release MaterialsSupramolecular Structure and Slow Release Property of Glyphosate Intercalated Layered Double Hydroxides, Chinese Science Bulletin, Vol. 50, No. 8, 745-751.

[5] Miyata, S. and Okada, A., 1976, Synthesis of new hydrotalcite-like compounds and their physico-chemical properties, Clays and Clay Mineral, 25, pp. 14-18.

[6] Tong, Z., Shichi, T. and Takagi, K., 2003, Oxidation catalysis of a manganese (III) porphyrin intercalated in layered double hydroxide clays, Materials Letters, 57, 2258-2261.

[7] Kloprogge, J.T., Hickey, L. and Frost, R.L., 2002, Infrared and Raman Study of Interlayer Anions $\mathrm{CO}_{3}{ }^{2-}, \mathrm{NO}_{3}{ }^{-}, \mathrm{SO}_{4}{ }^{2-}$ and $\mathrm{ClO}_{4}^{-}$in $\mathrm{Mg} / \mathrm{Al}$ Hydrotalcite, American Mineralogist, Vol. 87.

[8] Handayani, M., Eko S., 2009, Uji Persamaan Langmuir dan Freundlich pada Penyerapan Limbah Chrom (vi) oleh Zeolit Prosiding Seminar Nasional Sains dan Teknologi Nuklir PTNBR - BATAN Bandung. 